\title{
Formalizing the conceptual-applicative framework of smart textile fibers in medicine
}

DIANA LORETA PĂUN

DOI: 10.35530/IT.069.01.1458

CONSTANTIN SORIN PĂUN

EMILIA VISILEANU

LAURENTIIU ALEXANDRU CHIOTOROIU

SILVIA CHIOTOROIU

REZUMAT - ABSTRACT

\section{Formalizarea cadrului conceptual-aplicativ al fibrelor textile inteligente în medicină}

Articolul abordează probleme legate de domeniul disciplinar al chirurgiei medicale, care impune caracteristici deosebite ale fibrelor, cu potențial fizico-chimic și proprietăți de rezistență puternic controlate. Clasificările propuse și liniile de abordare a fibrelor textile în medicina generală și, în particular, în chirurgie, sunt de natură teleologică și, în egală măsură, reprezintă premise pentru o taxonometrie generică în domeniu. Propunerea originală în acest cadru este de abordare extinsă a multi-tipo-dimensiunilor de fire chirurgicale în intervențiile clinice specifice, pornind de la constatarea că, în fapt, cantonarea în tipo-dimensiunea fixă/forma exclusivă circulară a firului chirurgical înseamnă stagnare, temperarea inovarii de granita în domeniu.

Cuvinte-cheie: industria textilă, fibre textile inteligente în medicină, taxonometrie generică în domeniu

Formalizing the conceptual-applicative framework of smart textile fibers in medicine

The article addresses issues related to the discipline of medical surgery requiring special fiber features with physicochemical material potential and strongly controlled resistance properties. The proposed classifications and lines of approach of textile fibers in general medicine, and in particular in surgery, are of a teleological nature and equally are prerequisites for generic taxonomy in the field. The original proposal in this context is to expand the multi-type dimension of surgical wounds in specific clinical operations, starting from the finding that in fact cantoning in the fixed-type size/exclusive circular shape of the surgical thread means stagnation, moderation of innovation of rupture in the field.

Keywords: textile industry, smart textile fibers in medicine, generic taxonomy in the field

\section{INTRODUCTION}

The use of textile materials (fibers, fabrics, yarns, bands, etc.) in preclinical and clinical medicine implies a feasible knowledge of: 1) the physic-chemical properties of the textile material, 2) the structure explained by the properties, 3 ) the chain of molecules in the fibers of the fabric, 4) the considerable effects induced on the human body at the "fiber-skin" contact in surgery, etc. Textile fiber is the natural, artificial or composite material characterized by its long length, extremely low thickness (thinness), fineness and flexibility. It is recognized that in the usual manufacturing of textiles system, artificial polymers play a decisive role in vinyl (including acrylic), polyamides, polyolefin, polyesters, to which natural polymers, namely proteins and cellulose, are added. In clinical medicine, from the perspective of physical properties, basic requirements for textile fibers are imposed starting from: 1) breaking strength, 2) continuity, 3) as long as possible, 4) extensibility, 5) elasticity. In medicine, in our opinion, it is of interest to use "smart fibers" that could translate various values of medical knowledge recorded in surgical sites in the human body.

\section{RELATED LITERATURE}

In papers elaborated by Hearle J.W.S. and Morton W.E. (2008), [6], Horrocks A.R. and Anand S.C., (2000), [7], Dattilo P. et al., (2002), [3], Nelson G., (2002), [11], Czajka R., (2005), [2], Tao X., (2001),
[12], etc. there are presentations, descriptions, assertions, conceptual and practical approaches to textile fibers used increasingly in medicine. Intelligent/ smart textile and clothing are topics described by Mattila H., (2006), [10], also van Langenhove L., (2007), [13], describes significantly aspects related to smart textiles for medicine and healthcare. Particular concerns in the field are also found in the works carried out by Anand S.C., et al., (2005), [1], respectively Lymberis A. and Olsson S., (2003), [9], which highlights the role of biomaterials in the smart biomedical area. A particular sub-domain is that of the yarns of surgery textile fibres for suture. Textile surgical implants are used in methods of intracorporeally suturing issues (Ellis J.G., 2013), [4], which add method of attaching surgical needles to multifilament polyglycolic acid absorbable sutures (Epstein M. and Schmidt E., 1971), [5] It can be noticed that the scientific literature in the field has updated topics, and fiber textiles are perfected in line with the accelerated technological progress in invasive/non-invasive medicine.

\section{EXPERIMENTAL WORK}

\section{Methods, classification and specific remarks}

Some polysaccharide-type fibrous substances found in "chitin" are medical uses by derivative chitosan. In the context, the constituent presence of alginic acid occurs when the fibers obtained are highly crystalline 


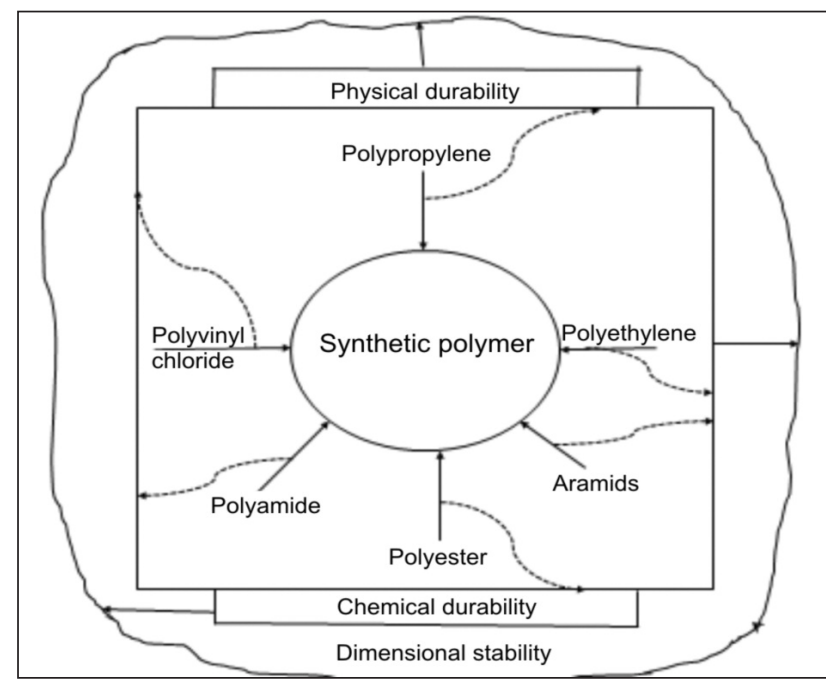

Fig. 1. Suitable synthetic polymers for medium to long applications in civil and agricultural engineering (Source: Authors, 2017)

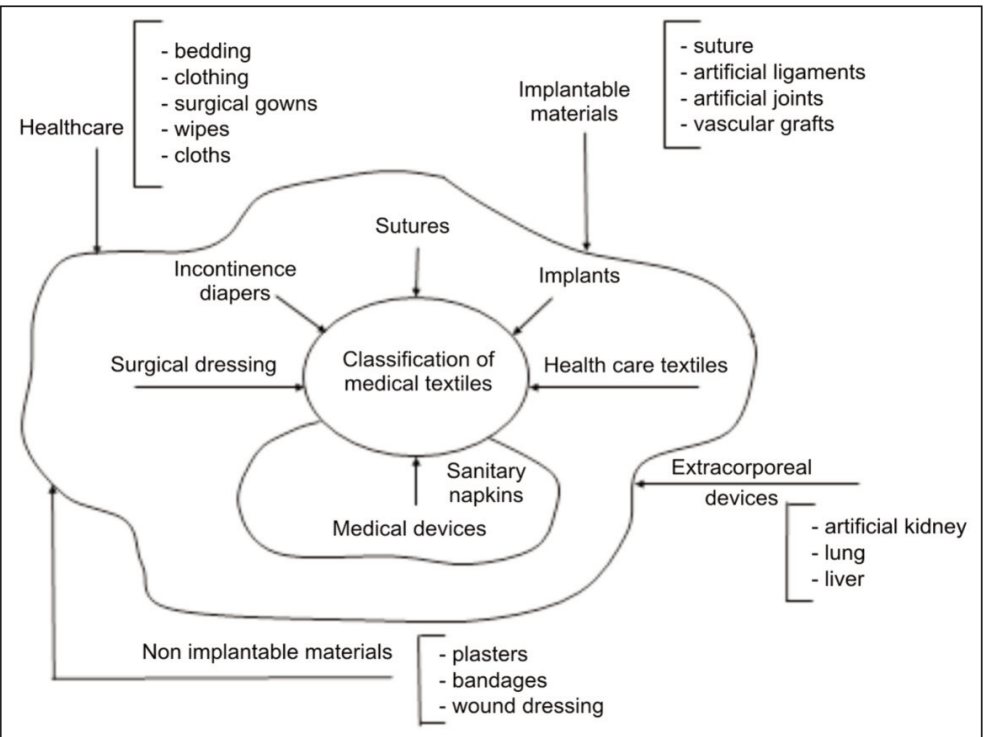

Fig. 2. Characterization of classification of medical textiles (Source: Authors, 2017)

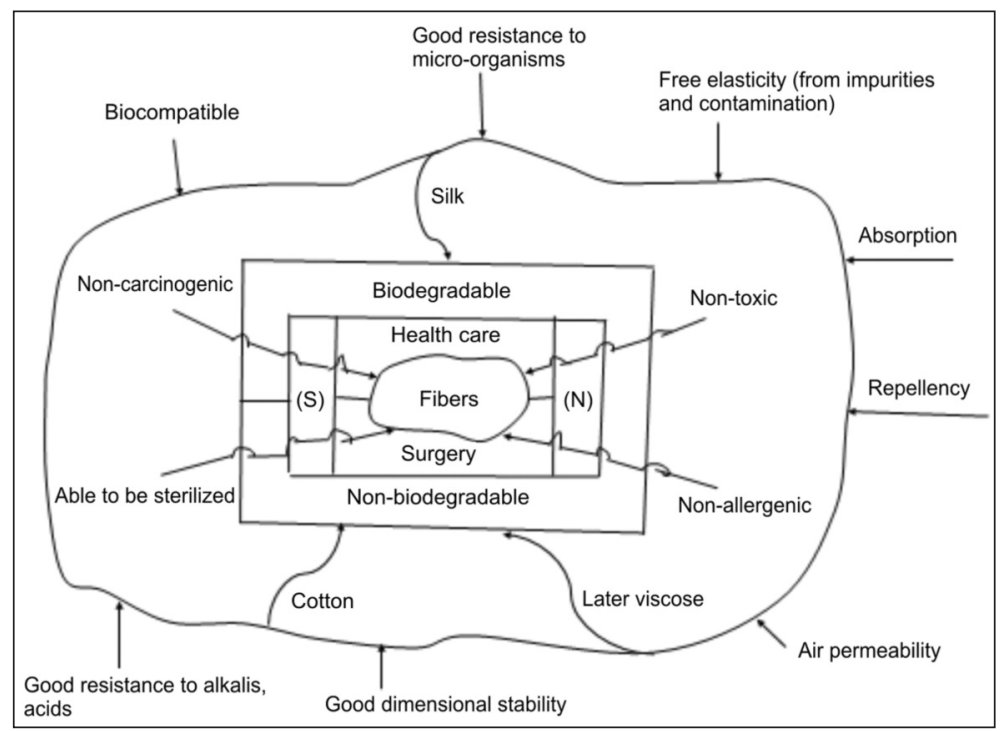

Fig. 3 Characteristics of textile fibers (types) used in health care and surgery. (Source: Authors, 2017) and real oriented. These yarns are subject to degradation because of their acidity, but different metal salts neutralize their rate of dissolution/disappearance. Medical fibers require biological compatibility. In the context, "smart fibers" have to prove special properties that mainly refer to radiation-absorbing, biological, electrical, diffusion, magnetic, etc. They could serve as thermo regulators, responsive to various stimuli, passive electronic instruments, transducers, etc. It is already recognized that certain substances/piezoelectric materials such as polyvinyl fluorides $\left(\mathrm{CH}_{2}-\mathrm{CF}_{2}\right)$ prove piezoelectric properties, configuring classes of particular polymers, and the addition of carbon to provide electrical conduction improves their range of uses in medicine. It is worth noting that in addition to the chemical and physicmechanical properties, the dimensions of medical textile fibers are of crucial importance in modern medical applications. Optimum lengths of $1-10 \mathrm{~cm}$, $0.1 \mathrm{~mm}$ convolution spacing, 10 micrometer diameter diameters, lamination up to 0.1 micrometers, making micro-fibrils with non-crystalline or crystalline areas with dimensions of $10 \mathrm{~nm}$ are dimensional requirements/already generally required for textile fibers used in medicine. Moreover, it reaches this frame and dimensions such as molecular width of $1 \mathrm{~nm}$, knowing that atoms of $\mathrm{C}, \mathrm{N}, \mathrm{O}, \mathrm{H}$ can reach $1 \AA\left(10^{-8}\right.$ $\mathrm{cm})$. In the traditional view, when the fibers are in the group it is appreciated that long fibers ensure cohesion, and short fibers sustain breaks. Typically, the fibers are present as amorphous sub-portions that support infrastructures: a) partially crystalline, b) linear polymers or c) partially oriented. Jeffries R., et al. (1969) [8], shows that structural clutter can occur in the textile material, for example when natural polymers such as celluloses are contacted with various other degradation substances. The author shows, by way of example, that the cotton effects in disordered textiles are: nonfreezing water $(16 \%)$, acid hydrolysis $(10 \%)$, alcoholysis $(10 \%)$, dinitrogen tetroxide oxidation $43 \%$ ), iodine sorption $(13 \%)$, etc. We find that synthetic polymers found in artificial textile fibers have applications in civil and agricultural engineering (figure 1).

Combination of medical science and textile technology offers a new research alignment and applications for medical textiles. We note, however, that the development of new fibers is conditional on manufacturing technologies (figure 2).

The disciplinary field of medical surgery requires, however, special features regarding fiber, which must have physic-chemical material potential and strongly controlled resistance properties (figure 3 ). 


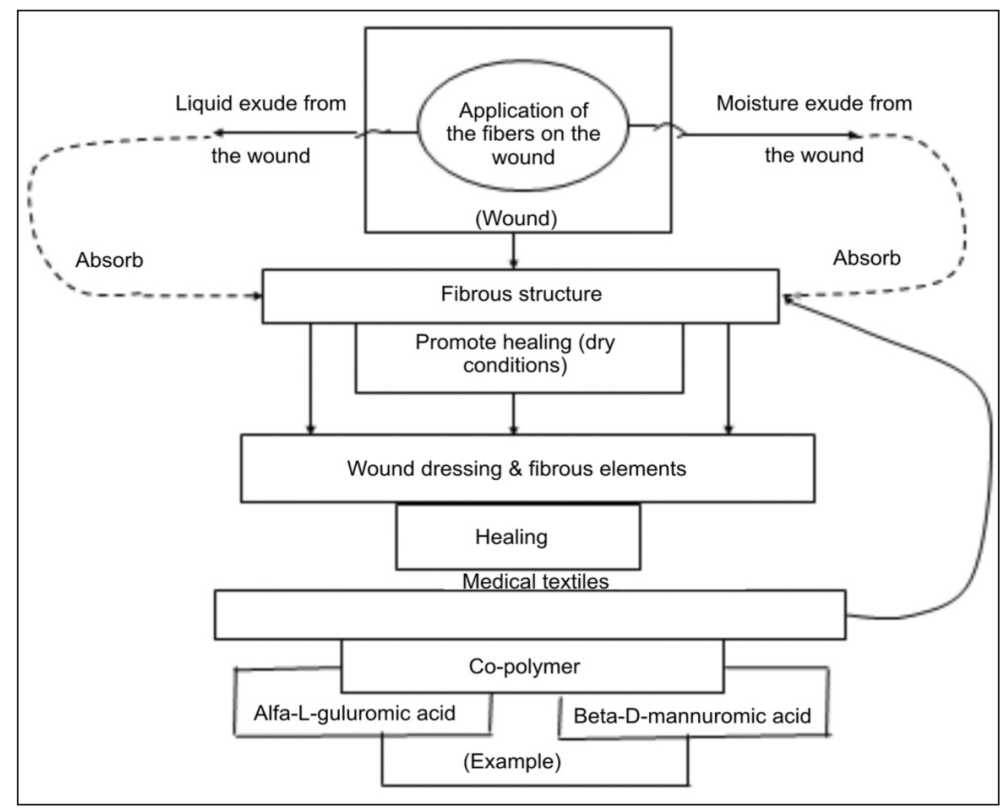

Fig. 4. Conditions of fibrous structure to respond compliant to applications on the wound. (Source: Authors, 2017)

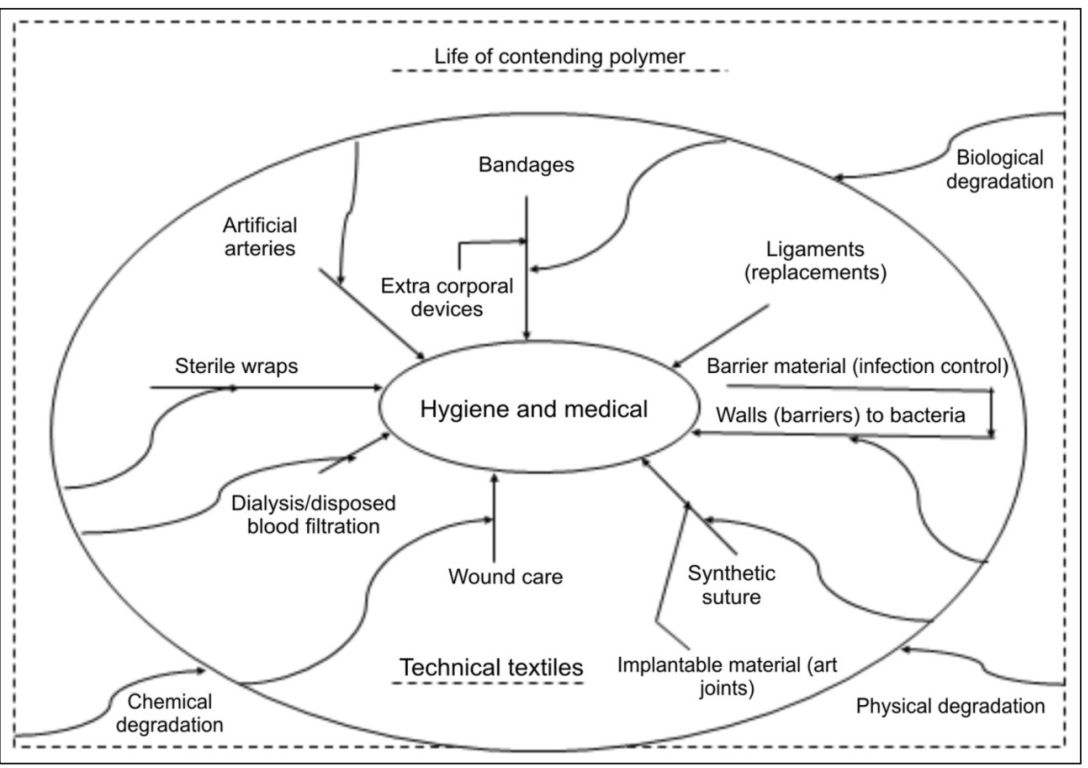

Fig. 5. Application of technical textile in hygiene and medical. (Source: Authors, 2017)

In the context, the fibrous structure must respond with real physical compatibility to the applications on the wound (figure 4).

In the same general medical framework, special textile fibers must respond with specific compatibility with the health and medical conditions (figure 5).

The above proposed classifications and lines for approaching textile fibers in general medicine, and in particular in surgery, are of a teleological nature and equally are prerequisites for generic taxonomy in the art.

\section{RESULTS AND DEBATES}

Characterization of intelligent/smart yarns/fibers in surgery operations

In surgery, the specific yarns/fibers used have the circular section, in all the usual cases, for all types of interventions known in the present, when there is a need for osmotic articulation of the different portions of the human body upon which incision has occurred. Circular sections $\left(S_{c}\right)$ are calculated with the relationship:

$$
\left(S_{c}\right)=\pi r^{2}
$$

with $r=$ radius (1/2 of the thickness) of the textile thread.

In the context, for a range $(0, \ldots, 1)$ it is possible to vary the circular section (thickness) as follows:

$$
\left(S_{c}\right)_{0}-\left(S_{c}\right)_{i}=\left(\pi r^{2}\right)_{0}-\left(\pi r^{2}\right)_{1}
$$

with the conditions:

$$
\text { 1) } \begin{array}{r}
r_{0}>r_{i} \sim\left(S_{c}\right)_{0}>\left(S_{c}\right)_{i}=\text { decreasing } \\
\text { thickness, (i) }
\end{array} \text { 2) } \begin{array}{r}
r_{0}=r_{i} \sim\left(S_{c}\right)_{0}=\left(S_{c}\right)_{i}=\text { maintaining } \\
\text { thickness, (ii) }
\end{array}
$$

The surgical user's case of special thread working in the operating theaters shows the quasi-absolute frequency of the situation (ii). Our proposal in this traditional setting is to expand the multi-type dimension of surgical thread in specific clinical operations, starting from the finding that in fact cantoning in the fixedtype size/exclusive circular shape of the surgical thread means stagnation, breakthrough innovations in the field. The advantages of such an approach are to establish an optimal linear density through the longitudinal variation of the size of the surgical cord radius, creating optimized quantitative desorption conditions in a controlled time. Next, it is possible to switch to the geometrical remodeling of the section of the surgical wires, reaching the ellipsoidal, rectangular, square, or irregular shapes of the sections, which, in accordance with the requirements of the surgical operations would mean the revolution of the products of this type in the field, chosen when feasible solutions are found for the biological degradation of technical textiles (figure 6).

In fact, we have to deal with the harmonization of the former sectional of the surgical thread with surgical suture requirements so that quantitatively and in time to provide optimized alignments for controlled, effective resorbtions. Some properties, such as torsional rigidity, degree of thickening, in/non-uniformity, variability of fineness, etc. are otherwise perceived/measured when considering transverse forms and dimensions. 


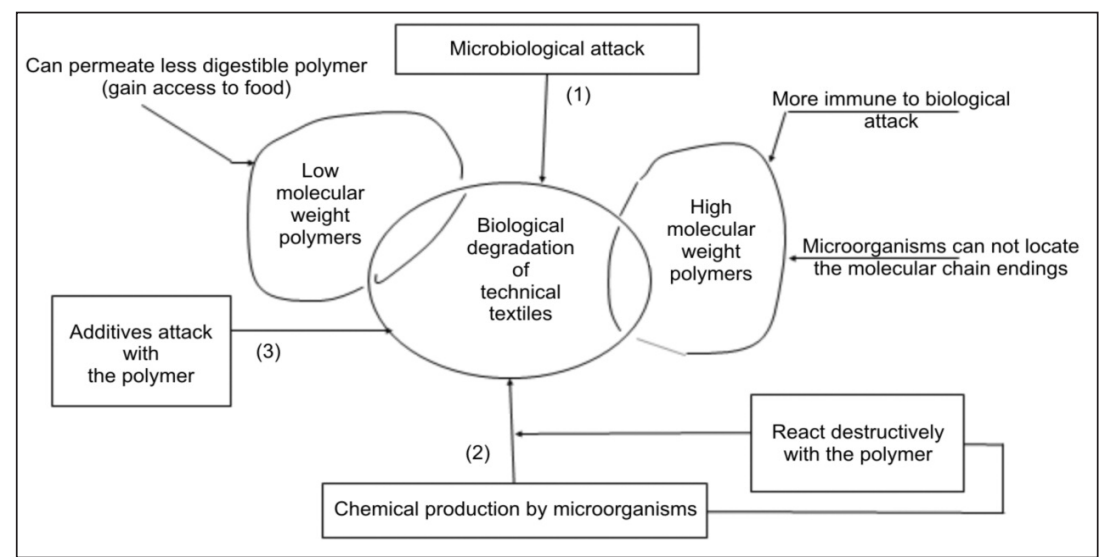

Fig. 6. Some issues on biological degradation in medical of technical textiles. (Source: Authors, 2017)

\section{CONCLUSIONS}

Geometric remodeling of the section of surgical wires means reaching the ellipsoidal, rectangular, square, or irregular sections of the sections. The requirements of the surgical operations are fulfilled and the products of this type are revolutionized in the field, for the biological degradation of technical textiles. The disciplinary field of medical surgery requires, however, special featurels regarding fiber, which must have physicochemical material potential and strongly controlled resistance properties. In the field of health, there are up-to-date topics, and fiber textiles are refined in line with advances in information technology accelerated in invasive/non-invasive medicine. It is recommended that an extended approach of multitype-sized surgical wires be performed in specific clinical surgery operations.

\section{BIBLIOGRAPHY}

[1] Anand, S.C., et al. Medical textile and biomaterials for helthcare, In: The Textile Institute, Woodhead PL, Cambridge, 2005.

[2] Czajka, R. Development of medical textile market, In: Fibres and Textiles in Eastern Europe, January/March 2005, vol. 13 , no. $1 / 49$.

[3] Dattilo, P. et al. Medical textiles application of an absorbable barbed bi-directinal surgical suture, In: Journal of Textile and Apparel, Technology and aManagement, vol. 2, Issue 2, Spring 2002.

[4] Ellis, J.G. US Patent, No. US5990378A, Mars 2013.

[5] Epstein, M., Schmidt, E. US Patent, No. US3736646A, 1971.

[6] Hearle, J.W.S., Morton, W.E. eds. Physical proprieties of textile fibres, In: The Textile Institute, Woodhead PL, Cambridge, 2008.

[7] Horrocks, A.R., Anand, S.C. Handbook of technical textiles, In: The Textil Institute, Woodhead PL, Cambridge, 2000.

[8] Jeffries, R., et al. Cell, Chem. Technol., 1969, 3, 255.

[9] Lymberis, A., Olsson, S. Intelligent biomedical clothing for personal health and disease management: state of art and future vision, telemedicine, In: Journal of e-health, vol. 9, Issue 4, December 2003, pp. 379-386.

[10] Mattila, H. Intelligent textile and clothing, In: The Textile Institute, Woodhead PL, Cambridge, 2006.

[11] Nelson, G. Application of microencapsulation in textiles, In: Intl. J. of Pharmaceutics, vol. 242, Issues 1-2, August 2002, pp. 55-62.

[12] Tao, X. Smart fibres, fabrics and clothing: fundamentals and application, In: The Textile Institute, Woodhead PL, Cambridge, 2001.

[13] van Langenhove, L. Smart textiles for medicine and healthcare: Materials, Systems and Applications, In: The Textile Institute, Woodhead PL, Cambridge, 2007.

\section{Authors:}

\section{DIANA LORETA PĂUN 1 , CONSTANTIN SORIN PĂUN², LAURENȚIU ALEXANDRU CHIOTOROIU³, EMILIA VISILEANU 4 , SILVIA CHIOTOROIU ${ }^{5}$}

${ }^{1}$ Senior Lecturer, Dr., PhD in Medicine, Carol Davila University of Medicine and Pharmacy, Bucharest / Manager National Institute of Endocrinology C.I. Parhon, Bucharest, 34-36 Bd. Aviatorilor, 011863, Bucharest, Romania

${ }^{2}$ Lecturer, Dr., PhD in Medicine, Carol Davila University of Medicine and Pharmacy, Bucharest / Floreasca Hospital, Bucharest, 8 Floreasca St., 014461, Bucharest, Romania

${ }^{3}$ Dr., PhD in Medicine, Floreasca Hospital Bucharest, 9 Floreasca St., 014461, Bucharest, Romania

${ }^{4} \mathrm{PhD}$. Engineering, Senior Researcher, I Dgr. Sci. Resch INCDTP, Bucharest, Romania

${ }^{5}$ Dr., PhD in Medicine, Malaxa Hospital, Bucharest, 12 Vergului St., 022441, Bucharest, Romania

e-mail: dianaloreta_paun@yahoo.ro,drspaun@yahoo.ro, chiotoroiu@yahoo.com,

visilean@ns.certex.ro, chiotoroiu@yahoo.com

Corresponding author:

LAURENȚIU ALEXANDRU CHIOTOROIU

e-mail: chiotoroiu@yahoo.com 